\title{
ANIMAL CLASSIFICATION
}

H.H.WILDER

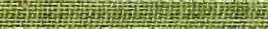

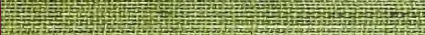

- 1 (1)

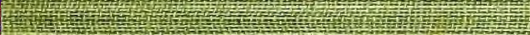

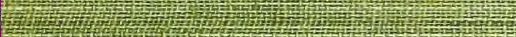

P(T)

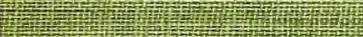




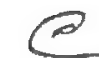

Q1) 352

W67

$-$

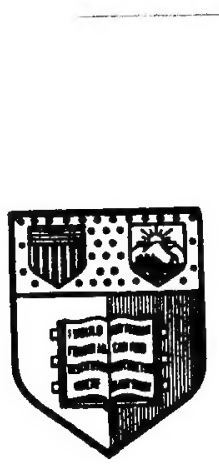

Selo 貼ark

Btate College of Agriculture At Cornell Hnibersitg

3tbaca, 今. $\mathbf{2}$.

İtoraty 
QL 352.W67 ${ }^{\text {Cornell University Library }}$

A synopsis of animal classification,

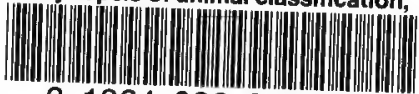

3 1924002815334

mann

\section{DATE DUE}

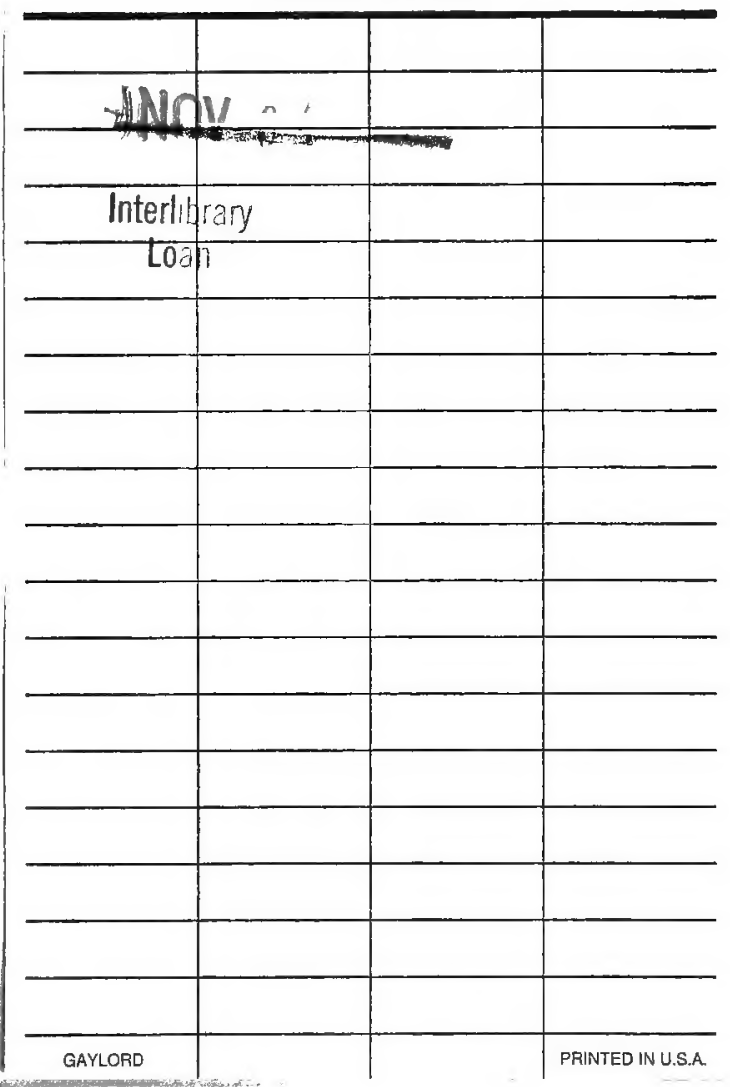




\section{Cornell University Library}

The original of this book is in the Cornell University Library.

There are no known copyright restrictions in the United States on the use of the text.

http://www.archive.org/details/cu31924002815334 


\section{A SYNOPSIS}

OF

\section{ANIMAL CLASSIFICATION}

BY

HARRIS HAWTHORNE WILDER, Ph.D.

Professor of Zoölogv in Smith College

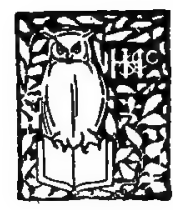

NEW YORK

HENRY HOLT AND COMPANY

1902 
(2)

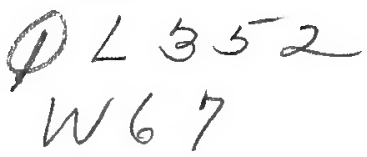

(e) 117,487

Copyright, 1902,

BY

HENRY HOLT \& CO.

ROBERT DROMOND, PRINTER, NEW YORK 


\section{PREFACE.}

THere is, perhaps, nothing about the science ot Zoölogy which is so much a matter of individual opinion as the method of classification of the various animal forms; and this is so in the nature of things, since a classification is at best but an artificial arrangement for convenience, and only in an incomplete and wholly inadequate way represents the actual relationships. These difficulties have led many teachers to practically disregard classification altogether; but what is thus gained in scientific accuracy is lost in clearness of arrangement, and the whole study is apt to seem vague and uncertain. It is to prevent this feeling of vagueness, and to furnish a foundation by means of which the facts ascertained by the student may be arranged in logical sequence, that $I$ have attempted this outline, and in this attempt I have sought to present a classification which is modern and rests upon a morphological basis, but is, at the same time, one that is dependent upon obvious points of structure, and is thus not too technical for the use of beginning students.

In the artificial key at the end there is no attempt at morphological grouping, and the characters emphasized are, as far as possible, the most obvious ones. Its main value is that of an index by means of which a student who investigates an animal for the first time may guide himself to the proper part of the synopsis without being under the necessity of applying to the instructor.

Dryads' GREen,

Northampton, Mass.,

September, I902. 



\section{A SYNOPSIS OF ANIMAL CLASSIFICATION.}

\section{MAIN SUBDIVISIONS OF ANIMALS.}

All known animals, both recent and fossil, may be conveniently grouped in the following eight subdivisions, or Types:

Type I. PRotozoA..........Amœba, Infusoria, monads, etc.

Type II. CGelenterata....Hydroid polyps, jelly-fish, corals, sponges, etc.

Type III. VERMES.......... Unsegmented worms, both free and parasitic; rotifers, brachiopods, etc.

Type IV. MOLLUSCA..........Bivalves, like clams and oysters; snails and slugs; cuttlefish, squid, etc.

Type V. ARTICUlata.......Segmented worms like earthworms and leeches; crustaceans, insects, spiders, mites, etc.

Type VI. echinodermata...Star-fish, sea-urchins, etc.

Type VII. PRevertebrata..Balanoglossus, tunicates, Amphioxus.

Type VIII. VERTEBRATA ...... Fishes, amphibians, reptiles, birds, and mammals.

The idea of thus arranging animals in Types or fixed groups developed mainly under the influence of Linnæus, Cuvier, and Agassiz, who taught that each Type was in itself absolutely distinct from all 
others and represented a certain definite plan of structure having no relation to the rest. Later investigation, however, has altered the significance of the Types, and what were once considered as distinct and unrelated animal groups are now seen to be but convenient divisions, based upon the actual structure of living animal forms and of the few extinct ones the remains of which have come down to us, and more or less organically connected with one another.

Among the modifications of this arrangement since the time of Cuvier are (I) the introduction of several new types, and (2) the grouping of the types thus established into larger groups in an attempt to express the various interrelations which exist between them. Thus the Protozoa, which are unicellular, and consequently without tissues, are contrasted with the Metazoa, which are multicellular, possess tissues and include all other animals.

The Metazoa, again, are divided into those composed of but two germ-layers and with a single internal cavity, and those composed of three germ-layers and with one or more cavities (coelomes) interposed between the central cavity and the exterior, the two groups thus representing a single and a double tube respectively. Of these the first includes the single Type of Cœlenterata (Type II), while the remainder are taken together to form the contrasting group of Cœlomata.

These latter Types (III-VIII) are again divided into three subdivisions, probably representing as many main branches or lines of descent : (I) the Zygoneura, including Vermes, Mollusca, and Articulata (Types III-V), and characterized by a nervous system of paired ganglia placed ventrally; (2) the Ambulacralia, including the single Type of Echinodermata (Type VI), animals which are bilateral when young and radiate when adult, and which are furnished by a watervascular system terminating externally in a series of ambulacral feet; and (3) the Chordata, which include the Prevertebrata and Vertebrata (Types VII, VIII), and are characterized by the presence of a dorsal nervous system and a central skeletal axis, the notochord, about which in the higher forms an internal skeleton becomes developed.

Certain of the Types include within their limits forms possessing structural differences of too fundamental a character to allow of their consideration as a single unified group, and yet conforming too closely in general plan to allow the formation of new Types. In such cases it 
is well to employ subdivisions, which may be called Sub-Types, and which will separate a Type into two or three distinct groups. Such divisions may be conveniently used in the case of the Colenterata, where the polyps and medusæ, the Ctenophores and the sponges all represent the Cœlenterate plan of structure, yet are radically different from one another, and in the Articulata, where the Annelids with their jointless appendages, the parapodia, may be separated from the Arthropods, which possess jointed limbs, the meropodia.

A summary of the above relations may be expressed by the following table, in which are expressed the grouping and subdivision of the Types :

\section{PROTOZOA.}

Type I. Protozon.

II. METAZOA.

A. CELENTERATA.

Type II. Coelenterata.

Sub-type I. Cnidaria.

Sub-type II. Ctenophora.

Sub-type III. Porifera.*

B. CELOMATA.

I) Zygoneura.

Type III. Vermes.

Type IV. Mollusca.

Type V. Articulata.

Sub-type I. Annelida.

Sub-type II. Arthropoda.

2) Ambulacralia.

Type VI. Echinodermata.

3) Chordata.

Type VII. Prevertebrata.

Type VIII. Vertebrata.

* According to the more usual arrangement of the three Sub-Types of the Colenterata the Porifera are placed first on the ground of the semi-independence of the cells and the consequent resemblance to a colony of Protozoa. In other respects, however, the Porifera are much modified and in their architecture and skeletal structure they are more complex than are the two other Sub-Types. 
The artificial character of this and all forms of classification is well seen in the fact that scarcely any two zoologists will agree exactly on the arrangement of the groups. Thus, with regard to the above table, some prefer to raise the three sub-types of Cnidaria, Ctenophora, and Porifera to the value of Types and to use the word "Colenterata" only as an antithesis to that of Colomata. Others regard the grouping expressed by the terms Zygoneura, Ambulacralia, and Chordata as of little value, and would employ the term "Chordata" as the equivalent of Vertebrata (Type VIII), or, again, would reduce the Types VII and VIII of the above table to the rank of sub-types under the Type Chordata. A common usage raises the "Sub-Type II. Arthropoda" to the rank of a Type, and unites "Sub-Type I. Annelida" to the Vermes (Type III). These differences of individual opinion rest upon the varied emphasis placed upon certain points of structure, or, perhaps, upon convenience to the memory and for purposes of instruction, and serve but to emphasize the facts that the animal forms available for study are but detached fragments of a once continuous history, and that the position of these fragments is in many cases a doubtful one. 


\section{THE TYPES IN DETAIL WITH THEIR SUBORDINATE GROUPS.}

\section{TYPE I. PROTOZOA.}

Unicellular organisms, single or colonial. Reproduction by fission or gemmation, also by conjugation, which may simulate sex-differentiation. Colonial forms may show a slight degree of polymorphism with division of labor, thus serving as transition forms between Protozoa and Metazoa.

Class I. RHIZOPODA............ No cell-wall ; move by pseudopodia.

Order I. Protoplasta.........Naked, or with shell made of chitin, sand-grains, etc., and containing a single large opening, out of which the animal extends its pseudopodia.

Sub-order I. Protoplasta

lobosa.............With thick, generally rounded pseudopodia.

x Amoba, Difflugia.

Sub-order 2. Protoplasta

flosa..............With fine, thread-like pseudopodia.

$\times$ Euglypha.

Order 2. Foraminifera...... Calcareous shell, perforated with innumerable fine openings; all marine. $\times$ Globigerina, Rotalia.

Order 3. RAdiolaRia ........ Silicious shell, generally lace-like; marine.

$x$ Thalassicolla, Acanthometra. 
Order 4. HeLiozoA........ Usually fresh-water forms; mostly spherical in shape, with silicious spicules.

$x$ Actinophrys, Clathrulina.

Class II. INFUsoria......... Cell-wall present, furnished with cilia or with knobbed tentacles.

Order I. Ciliata............ Body ciliated; usually locomotive; a few sessile forms.

Sub-order I. Holotricha.... Cilia uniformly covering the body. $x$ Paramocium.

Sub-order 2. Heterotricha ... Cilia in patches, and often of different lengths. $x$ Stentor.

Sub-order 3. Peritricha...... Cilia in a ring around the mouth. $\times$ Vorticella, Epistylis.

Sub-order 4. Hypotricha .... Cilia only underneath; creeping forms.

$\mathrm{x}$ Stylonychia.

Order 2. Suctoria........... Certain areas of body prolonged into attenuated tentacles tipped with adhesive knobs. $\quad \times$ Acineta.

Class III. MASTIGOPHORA ...... Cell-wall present; move by one or more flagella; solitary and colonial forms.

Order I. Nudoflagellata... . Simple monads, solitary or colonial. $x$ Cercomonas.

Order 2. Choanoflagellata. . Collared monads, often colonial. $x$ Codosiga.

Order 3. Cilioflagellata.... Mostly marine forms, with siliceous exoskeleton.

$x$ Ceratium, Peridinium.

Order 4. Cystofiageldata.... Large marine forms, with reticulated endoplasm. $\quad x$ Noctiluca.

Supplementary Order. Volvocins: Large, spherical colonies containing specialized macro- and microzooids for reproduction. May probably be classed as plants.

Many of the lower plants are, at least in certain stages, typical Flagellates, and thus the plants and animals come in contact at about 
this place. In many cases it is impossible to tell with certainty whether the organism in question is a plant or an animal, and the decision rests upon a common agreement rather than upon any definite structure or physiological reaction.

Class IV. SPOR0Z0A...........Parasitic Protozoa with a complicated life-history, one stage of which is usually a cyst or case containing numerous minute individuals called spores. Recently this class has acquired a great though unpleasant notoriety through the establishment of the fact that several of our worst diseases, such as malarial and yellow fevers, are caused by members of this group, one stage of which is passed in the human blood, while various species of mosquito serve as the intermediate host.

$x$ Monocystis (in earthworms). Hamamceba (in blood of vertebrates and in insects).

\section{TYPE II. CCELENTERATA.}

Animals built on the plan of a Gastrula, i.e., that of a cup or vase with double walls, ectoderm and endoderm; with a large central cavity, the gastrocœle, and with a mouth or protostome. They are strictly radial in structure and possess a central axis and two poles, oral and apical. The parts are arranged about the axis in $2^{s}, 4^{s}, 6^{s}$ and their multiples. A fundamental difference in the three sub-types, although seen in some of them only in the embryo, is the difference in development and use of the apical pole.

In the sessile Cnidaria it is used as the point of support, and is non-sensitive in the free-swimming ones; in the Ctenophora it is directed forward during locomotion and bears the principal senseorgans; and in the Porifera it is the point at which the excurrent orifice, the osculum, is situated. 


\section{SUB-TYPE I. CNIDARIA.}

Sessile forms known as polyps, and free-swimming ones known as medusce, often occurring as various generations of the same species. Tentacles are almost universally present, and these and other exposed parts are armed with cnidoblasts, or "nettle-cells."

Class I. HYDROZOA...........Animals based upon the plan of a simple polyp, the Hydrula.

Order I. AuthydRz..........Polyps which produce other polyps without an intervening medusageneration.

Sub-order I. Hydrida....... Simple, fresh-water polyps. Individuals solitary, not forming colonies. Reproduce asexually in summer and sexually at the approach of winter. $\quad x$ Hydra.

Sub-order 2. Hydrocoralline. Tropical marine forms in polymorphic colonies, producing a sort of coral.

$\times$ Millipora.

Order 2. Hydro-Medus $\approx$......Polyps of the hydrula form, and small medusæ with velum; these forms usually appear as alternate generations of the same animal.

Sub-order I. Gymnoblastea-

anthomedusa ........... Sessile colonies of polyps with reproductive medusæ, free or reduced. The polyps are naked, i.e., not protected by the perisarc. The medusæ possess ocelli and genital organs in the manubrium. $x$ Pennaria (with reduced medusæ). Podocoryne (with free medusa, the form called Dysmorphosa).

Sub-order 2. Calyptoblastea-

leptomedusce............ Sessile colonies of polyps with reproductive medusæ, free or re- 
duced. The polyps are protected by cups formed of the perisarc. The medusæ possess otocysts and genital organs on the radial canals.

$x$ Campanularia.

Sub-order 3. Trachymeduse..Free-swimming medusæ with velum, 4-6 radiating canals and other characteristics of Hydro-medusæ, but with direct reproduction and no polyp generation.

$x$ Liriope, Geryonia.

Sub-order 4. Siphonophora...Free-swimming colonies of polymorphic individuals representing both types (polyp and medusa) and characterized by a complex of several individuals, known as a Cormidium.

$x$ Velella (with free medusæ). Physalia (with reduced medusæ, which remain attached to the colony).

Class II. SCrPHOZ0A..........Animals based upon the plan of a polyp with invaginated manubrium, and with mesenteries, the Scyphula.

Order I. AnthozoA......... Scyphula polyps which produce other polyps without medusa generation; thus corresponding to the Authydre above. Mostly coral producers.

Sub-order I. Hexacoralla.... Mesenteries and other parts in 6 . Some forms (the "sea-anemones") produce no coral; others form at the base of the polyps a solid mass, often branched, and showing pits and radiate partitions to mark the site of the individual polyps. x Metridium, Fungia. 
Sub-order 2. Octocoralle.... Mesenteries and tentacles always eight; coral consists of a horny axis about which is built a polyparium containing calcareous spicules called sklerites.

Renilla, Corallium.

Order 2. Scypho-Medusx....... Large medusæ without velum, which are produced by minute polyps of the scyphula type. This order corresponds to that of the Hydro-medusa above, although here the medusa form is by far the most in evidence.

Cyanea, Aurelia.

Supplementary class : PlanuloIdea. Minute endoparasites, without mouth or intestinal lumen, resembling the Planula larva of Cnidarian polyps. There are two groups: the Dicyemida, found in the nephridia of Cephalopods, and the Orthonectide, in Ophiuridea, Turbellaria, and Nemertea. They have been considered as "Mesozoa," intermediate between Protozoa and Metazoa, but are more probably Cnidaria, reduced by parasitism.

\section{Sub-TYPE II. CTENOPHORA.}

Floating pelagic forms, transparent and gelatinous, with eight rows of swimming-paddles. Structure a modified radiate or doubly bilateral one. No nettle-cells, but somewhat similar organs, and adhesive cells.

Class I. TEntaculata........ With two long prehensile threadlike tentacles. $\times$ Pleurobrachia. Class II. NUDA............ Tentacles wanting. $\quad \times$ Beroè.

\section{SUb-TYPE III. PORIFERA.}

The typical members of this group are shaped like polyps without tentacles, but with the lateral walls perforated by numerous incurrent pores and with a large excurrent orifice, the osculum, at the top. They possess between ectoderm and endoderm a mass of cells, the mesenchyme, containing spicules or a network of hornthreads. The more modified forms often grow into masses, the individuals of which cannot be definitely distinguished. 
II. TYPES IN DETAIL WITH THEIR SUBORDINATE GROUPS. II

Class I. CALCiSPONGIA........ Skeleton composed of calcareous spicules, the typical form of which is a three-pointed star.

Order 1. Asconida...........Wall of sponge not folded-main cavity lined with digestive cells.

$$
\times \text { Ascetta. }
$$

Order 2. Sxconida..........Wall of sponge forming oblong chambers opening directly into the main cavity. Digestive cells confined to the chambers.

$x$ Sycandra.

Order 3. Leuconida.......... Wall of sponge with a very thick mesoderm, in which are spherical chambers lined with digestive endodermal cells. Chambers connected with the exterior and with the main internal cavity by branching canals. $\quad x$ Leucandra.

Class II. SILICISPONGIæ........ Skeleton composed of silicious spicules, often in the form of simple rods, or in some cases showing designs based upon the number 6 .

Order I. Tetractinellide.... Skeleton containing four-rayed spicules.

Order 2. HexactineLLIDE..... Skeleton containing six-rayed spicules. $\quad x$ Euplectella, Hyalonema. Class III. KERATOSPONGIE..... . Skeleton of chitinous threads forming a network, sometimes reinforced by silicious spicules.

$\times$ Euspongia.

\section{TYPE III. VERMES.}

A large and heterogeneous group of low Invertebrates placed for convenience under a single Type. Although many members of the group are cylindrical and worm-like in shape, there are many other forms included. They are all soft-bodied, with a thin external cuticle, and with no internal skeleton. None are segmented, 
although in one group a reduplication of certain parts resembles a definite segmentation. The nervous system consists of a central ganglion at the anterior end, from which extend longitudinal cords which in the case of the more attenuated forms may become a complicated system with transverse commissures. Many are sessile or possess organs for temporary attachment; in the locomotive forms motion is effected by contractions of a subcutaneous muscular layer, or in a few primitive and minute forms, by a band of cilia, the trochus. A large number of Vermes are parasitic.

Class I. PLATYHELMINTHES. .... Vermes flattened dorso-ventrally, and with the body-cavity entirely filled with a tissue known as Parenchyma, necessitating in the larger forms a dendritic branching of alimentary and other systems. Intestine incomplete (i.e., without anal orifice). Hermaphroditic.

Sub-class I. TURBellaria........ Free-swimming Platyhelminthes, of oval shape; body very contractile and covered with cilia.

Order I. RhaBdocata........ Intestine a straight, unbranched tube. $x$ Mesostomum.

Order 2. TricLadA........... Intestine dendritic, with three main trunks-one anterior and two posterior.

$x$ Planaria.

Order 3. Polyclada......... Intestine like foregoing, but with more than two posterior branches.

$x$ Planocera.

Sub-class II. Trematodes....... Parasitic Platyhelminthes. Boyd not ciliated in the adult, but generally furnished with sucking-discs. Intestine much as in Triclada.

Order I. Monogenea.......... Ecto-parasites upon gills, integur ment, bladder, etc., of aquatic vertebrates. Sucking-discs, three omore. Development direct. $x$ Polystomum. 
Order 2. Digenea............ Ento-parasites with never more than two sucking-discs. Development by heterogony, through forms known as sporocyst, redia, cercaria, etc., which inhabit several hosts, the first being a pond-snail or some allied form.

x Fasciola (Distomum). Sub-class III. Cestodes.........Ento-parasitic Platyhelminthes without intestine. Adult form generally composed of links (proglottids). Larval form (cysticercus) provided with sucking-discs, and often hooks. In the typical forms the cysticercus encysts itself in the muscles or internal organs of its first host, and develops into the link-form only when swallowed by some special animal, which thus serves as its second host.

$\times$ Tania.

Supplementary group : NemerteA or NEMERTini. A group of freeliving worms, mostly marine, with a few representatives in fresh water and in damp earth. Their position in the system is uncertain, but they seem in most characteristics to be allied to the Platyhelminthes. Like them they are dorso-ventrally flattened, and possess lateral excretory canals and diverticula to the intestine; their nervous system is also similar. They differ, however, in the possession of a body cavity, a set of blood-vessels, and a complete alimentary canal with anus. At their anterier end they possess a long retractile proboscis. The more typical marine forms have a minute ciliated larva called a pitidium. Some are small, a few marine forms attain a great length (30-40 feet). They are divided into three orders, as follows :

Order I. HOPLONEMERTINI....... Proboscis armed with bristles.

$x$ Tetrastemma.

Order 2. Schizonemertini ..... Proboscis unarmed, head nearly divided by deep, longitudinal fissures. $\times$ Cerebratulus.

Order 3. Paleonemertini ..... Proboscis unarmed. Head nearly entire.

$x$ Cephalothrix.

Class II. Nemathelminthes...Cylindrical worm-shaped Vermes, possessing a body cavity. Intes- 
tine, when present, usually complete.

Sub-class I. Nematodes ......... Long, cylindrical unsegmented worms. Body not contractile but very pliable. Two lateral excretory canals. Intestinal canal long and straight, with mouth and anus generally present. Sexes usually separate. Free-swimming and parasitic forms.

$\times$ Ascaris, Trichina.

Supplementary form. Sagitta, a small marine worm with caudal and lateral fins, and a paired group of bristles which serve as jaws. Is assigned to a separate order-Chatognatha. [Cf. p. 2I.]

Sub-class II. ACATTHOCEPHALI. ...A single family of worms, externally similar to last, but with an anterior extensile proboscis beset with hooks, and no intestinal canal. Larval stage in crustaceans and insects; adult in intestine of vertebrates. $\quad x$ Echinorhynchus.

Class III. TROCHELMINTHES.... Vermes of various shape, never worm-like, and usually minute. The locomotive species possess a ciliated band or trochus, which, in the sessile forms, is represented by ciliated tentacles.

Sub-class I. Rotirera........... Minute locomotive Trochelminthes, with ciliated areas and generally a few posterior segments.

Order I. Cephalotricha..... True roti-fers (i.e., wheel-bearers), with cilia at the anterior end, usually covering two protrusible organs resembling wheels.

x Brachionus, Rotifer. 
II. TYPES IN DETAIL WITH THEIR SUBORDINATE GROUPS. I5

Order 2. Gastrotricha......A few forms with a ciliated ventral surface. These are considered by some as forming an independent sub-class, closely allied to Rotifera.

$\mathrm{x}$ Ichthydium.

Sub-class II. BRYOZOA (POLXZOA) . . Minute forms, usually encased in chitinous tubes or " cells." Generally colonial, and then often bearing a superficial resemblance to a hydroid or an alga. Intestine U-shaped; mouth surrounded by a ridge (lophophore) bearing ciliated tentacles.

Order I. Phoronidea.........Worm-like forms, enclosed ir. leathery tubes. One genus, $P$ horonis.

Order 2. Endoprocta..........Anus included within the lophophore. Tentacles only partially retractile. All marine.

$x$ Crnatella, Loxosoma.

Order 3. Ectoprocta..........Anus outside the lophophore. Tentacles completely retractile. A few fresh-water forms, the rest marine. $\quad x$ Bugula, Plumatella.

Sub-class II. BRACHIOPODA....... All marine, depressed in form, with dorsal and ventral shells which are symmetrical, but unequal. Mouth situated between two spiral ciliated arms, which lie coiled up in the shell. A large fossil order. Few living.

Order 1. Ecardines.......... Shell without a hinge. $x$ Lingula. Order 2. Testicardines....... Shell with hinge; usually calcareous loops to support arms.

$\times$ Terebratulina. 


\section{TYPE IV. MOLLUSCA.}

Soft-bodied, unsegmented animals, consisting typically of three parts: head, foot, and visceral sac; this latter part is covered dorsally by a duplicature of integument called the mantle, the outer layer of which usually secretes a calcareous shell, consisting of one, two, or several separate pieces, which sometimes depart from the original bilateral symmetry; a complicated vascular system with a pulsating heart and typically one or more pairs of plumose gills, the ctenidia, which may be variously modified or entirely replaced by other organs; nervous system composed of several pairs of ganglia; body cavity restricted to a small open space surrounding the heart.

Class I. AMpHINEURA.........A small group of bilaterally symmetrical molluscs showing similarity to the Turbellaria. They have a nerve-ring around the mouth and four parallel longitudinal nervecords connected by transverse commissures.

Order I. Solenogastres. ......Mantle and shell wanting. Body worm-like.

$x$ Proneomenia.

Order 2. Chrtones..........With a dorsal shell composed of eight transverse pieces.

$x$ Chiton.

Class II. PELECYPODA (Lamelli-

branchiata)............. Bilaterally symmetrical, or, in a few cases, secondarily distorted, owing to an habitual lateral position; two lateral shells, usually united dorsally. The single pair of ctenidia seldom appears in a simple form, in most cases the separate plates are elongated and filiform, and are often doubled upon themselves and united together in such a way as to form two thin lamellæ upon each side. They 
are without a distinct head and lack a "lingual ribbon" or radula. The foot is compressed and never forms a creeping disc.

Order I. Protobranchia......With normal, doubly pinnate ctenidia extending backwards in the mantle cavity, and free, except at the base.

$\times$ Nucula, Yoldia.

Order 2. Filibranchia........ Separate plates of the ctenidia filiform and greatly lengthened, and folded back upon themselves. The separate filaments are free from one another, but are so closely approximated that they give the appearance of continuous plates.

x Mytilus, Arca.

Order 3. Pseudolamellibran-

cHIA ................. Similar to the last, but with slight adhesions between the separate filaments, caused by ciliated surfaces; also with a few cross-bars, with vascular connexion between the descending and ascending limbs of each filament and with a vertical folding or crimping of the lamellæ as a whole, forming ridges and depressions. $\quad x$ Pecten, Ostraa.

Order 4. Eulamellibranchia... Filaments so completely fused as to be no longer recognizable as such, and with the descending and ascending lamellæ thus formed so frequently united by their adjacent surfaces that the entire ctenidium of one side appears in the form of two gill-plates, a characteristic once used as typical of the class 
("Lamellibranchiata"). The great majority of the Pelecypoda are here included. $\quad \times M y a$, Venus.

Order 5. Septibranchia....... Ctenidia reduced to muscular partitions perforated by rows of gill slits and dividing the mantle cavity into two compartments.

x Silenia.

The following somewhat older classification of the Pelecypoda was based upon the presence or absence of a siphon and the conditions of the adductor muscles, a system which had the advantage of being applicable to the shells from which the soft parts have been removed, but which is not so fundamental morphologically as the present one.

Order I. SIPHONIATA.......... With two posterior siphons, separate or fused. Edges of mantle often joined.

Sub-order 1. Sinupalliata.... Siphons long and contractile. Pallial line with sinus. $x$ Mya, Venus, Solen.

Sub-order 2. InTEgripalliata..Siphons short, not contractile. No pallial sinus. $x$ Cyclas.

Order 2. Asiphonia ............ Siphons absent.

Sub-order I. Homomyaria..... Anterior and posterior adductor muscles about equal. $x$ Unio.

Sub-order 2. Heteromyaria... Anterior adductor very small. $x$ Mytilus.

Sub-order 3. MONOMYARIA..... Anterior adductor wanting. $x$ Ostraa, Pecten.

Class III. SCAPHOPODA........ Bilaterally symmetrical molluscs with visceral sac greatly elongated in a dorso-ventral direction. Mantle and shell tubular and somewhat curved, with a smaller dorsal and a larger ventral opening. Ctenidia fail. Foot elongated and conical. A single family of marine forms. $\quad x$ Dentalium.

Class IV. GASTEROPODA........ Molluscs with a head, foot, and visceral sac. The first two are bilateral; the third is generally contained in a spirally twisted 
shell, usually capable of receiving the other parts when retracted; mouth furnished with a radula; foot forming a creeping disc.

Order I. Prosobranchiata.... Shell present; gill anterior to heart; foot a creeping disc; sexes separate.

$\times$ Oliva, Cyprcea, Strombus.

Order 2. Heteropoda........ Shell small or wanting; gill as in previous order; anterior part of foot compressed, forming a sort of keel ; sexes separate. This order includes a very few nearly transparent forms, which swim on the surface of the ocean.

$x$ Carinaria.

Order 3. Pulmonata......... Land and fresh-water snails breathing by plexus of blood-vessels which lie in a respiratory chamber communicating with the exterior, and placed anterior to the heart; shell generally present; hermaphroditic. $\mathrm{x}$ Helix, Limnaa.

Order 4. Pteropoda......... Shell fragile or wanting, foot developed into a pair of wing-like expansions, hermaphroditic. A small group of forms which swim at night upon the surface of the ocean.

$x$ Cymbuliopsis.

Order 5. Opisthobranchiata... Shell, when present, rather delicate, often wanting; gill placed behind heart; back of naked forms often ornamented with simple or dendritic papillæ; hermaphroditic. $\times$ Bulla, Eolis.

Class V. CEPHALOPODA......... Head well developed, distinct from body and with two large eyes; mouth surrounded by many arms 
or tentacles; foot rolled into a
sort of funnel.

Order 1. Dibranchiata.......Gills two; eight or ten arms around the mouth, covered with cup-shaped sucking discs; ink-bag present; shell internal (in Argonauta not entirely covered).

$\times$ Loligo, Octopus.

Order 2. Tetrabranchiata.... Gills four, mouth surrounded by numerous unarmed tentacles; inkbag wanting; a heavy external shell divided into chambers. A single living genus. $\times$ Nautilus.

The present Cephalopods are the few degenerate descendants of a very large and abundant group, which filled the seas in Palæozoic and Mesozoic times. They possessed, originally, well-developed shells, divided into chambers; some shells being straight, others spirally coiled. The Tetrabranch, Nautilus, is the only living representative of the great Order NAUTILOIDEA, and still retains a heavy chambered shell. The other great Tetrabranch Order, the AMMONOIDEA, is entirely extinct. These possessed spirally wound shells with chambers and septa, the latter often fluted and otherwise ornate. The BELEMNOIDEA were Dibranchs. They possessed usually straight shells, and were the ancestors of the modern squid.

\section{TYPE V. ARTICULATA.}

Segmented bilateral animals, with a chitinous exo-skeleton which varies in thickness from a thin skin to a hard shell, reinforced by mineral salts. Body cavity present and spacious; alimentary canal complete, approximately coinciding with the longitudinal axis; nervous system a double chain of ganglia, typically a pair for each somite; vascular system consists of a longitudinal dorsal vessel, and generally one or more ventral ones, connecting with the dorsal one by commissures. Sexes almost always separate.

Sub-type I. ANNELIDES....... Primitive Articulates, worm-like in appearance and without jointed limbs or definite somite-complexes. Body cavity divided by dissepiments into somitic divisions. 
II. TYPES IN DETAIL WITH THEIR SUBORDINATE GROUPS. 2 I

Class I. CHetOPODA........... Typical Annelids, with wellmarked external somites, corresponding to the internal metamerism; somites furnished with paired groups of chitinous bristles.

Order I. Polycheta.......... Bristles conspicuous, situated on raised lateral portions, the parapodia. Head generally present. $\times$ Nereis, Serpula.

Order 2. Oligocheta......... Bristles very small, sunk in hollows along the sides; no parapodia; no distinct head; hermaphroditic. x Nais, Lumbricus.

Class II. HIRUdINEA. . . . . . . Aquatic hermaphroditic ecto-parasites; segments without bristles; move by terminal, adhesive suckers. External and internal segments do not correspond.

Order I. RhynchoвdeLlide....Pharynx extensile, forming a sort of proboscis. $x$ Clepsine.

Order 2. Gnathobdelimide.... Pharynx not extensile, with three longitudinal ridges which are often toothed.

$x$ Hirudo.

\section{SUPPLEMENTARY CLASSES (PROBABLY RELATED TO ANNELIDS).}

Class CHeTIFERA, formerly taken with Sipunculoidea to form Class Gephyrea. Here belong a very few marine worms, Echiurus, Bonellia, etc., which show affinities to the Chatopoda. They are segmented only as larva, but possess paired nephridia and a system of blood-vessels similar to that of Annelids.

Class SIPUNCULOIDEA includes a very few forms of marine worms, bearing some slight affinity to Annelids. They were formerly united with Chrtifera to form the class Gephyrea. They are cylindrical, unsegmented forms without bristles, and possess a retractile proboscis.

$\times$ Sipunculus, Phascolosoma.

Class Chetognatha. This includes one form, Sagitta, a small, transparent, unsegmented worm found on the surface of the ocean. The body is flat and possesses lateral fin-like extensions. The mouth is armed with jaws beset with sharp hooks. Hermaphroditic. It develops lateral cœlom sacks, which appear to have the value of a metacœlom. It is placed by some with the Nematodes. [Cf. p. I4.] 
Sub-type II. ARTHROPODA... More specialized Articulates with jointed appendages (meropodia) and with somites grouped to form three somite-complexes, head, thorax, and abdomen. These may be distinct or fused, either as cephalothorax and abdomen or as a single piece. Internally the cavities of the somites are confluent, without dissepiments.

Class I. CRUStacea...........Aquatic Arthropods, with two pairs of antennæ and numerous pairs of appendages, usually showing much differentiation. Respiration either through the general surface of the body or by localized thin places, in the form of plates or dendritic structures, upon or near some of the appendages. A few are secondarily adapted to a terrestrial life.

Sub-class I. Entomostraka..... . Small, often minute Crustacea with a variable number of somites. Abdomen generally without appendages.

Order I. Phyllopoda.......... Numerous (10-40) pairs of flattened, leaf-like legs, bearing sacshaped gills.

$\times$ Branchipus.

Order 2. Cladoctra........... Body enclosed in lateral integumental duplicatures, forming a twovalved shell which usually covers thoracic and abdominal regions, but leaves the head free. Second pair of antennæ enormously developed and used as oar-like organs of locomotion.

$\times$ Daphnia.

Order 3. Copepoda.......... Body generally elongated and with- 
out integumental duplicature. Four to five pairs of flattened, two-branched legs used as oars. Eggs carried in two lateral sacs on the sides of the abdomen. Many forms reduced by parasitism.

$\times$ Cyclops, Lerncea, Argulus.

Order 4. Ostracoda..........Body, including head, enclosed in a bivalve shell, with hinge and adductor muscle. Seven pairs of appendages, of which only 2 (or 3 ) may be reckoned as legs.

$x$ Cypris.

Order 5. Cirripedia.......... Free-swimming only when young. Adults become sessile and are enclosed in an inverted position in a calcareous two-valved shell. Generally six pairs of twobranched legs, modified to form delicate many-jointed cirri.

$x$ Lepas, Balanus, Sacculina.

Sub-class II. malazostraxa ... Generally large forms with a constant number of somites (20), consisting of a head with five, a thorax with eight, and an abdomen with seven somites. The first two portions are often fused to form a cephalo-thorax of thirteen somites. Only the first six abdominal somites bear appendages, and of these the last pair is generally modified and united with the terminal somite to form a caudal appendage. The paired reproductive orifices of the male are found upon the last thoracic legs, near the base, and those of the 
female upon the third from the last.

The numerous Orders inciuded under this sub-class are arranged for convenience into larger groups, which may be designated as "superorders " or "legions," and which facilitate the classification.

Super-order I. LEPTOSTRAKA

(with a single Order)

Order I. Phyllocarida...... This group, mostly fossil, contains but a single living form, valuable as a link between Entomostraka and Malakostraka. A small integumental duplicature covers the head and thorax. The abdomen is 8 -jointed, thus departing from the constant number otherwise found in Malakostraka. The feet are like those of phyllopods.

$\times$ Nebalia.

Super-order 2. ARTHROSTRAKA. . Sessile-eyed Malakostraka, with free thoracic segments, and without carapace. Thoracic appendages distributed as one pair of maxillipeds and seven pairs of legs. Brood cavity borne between thoracic legs.

Order I. Amphipoda.......... Compressed forms, body generally bent into a curve. Seven free thoracic somites. Gills upon the thoracic legs. Abdomen with six pairs of legs, of which the first three are used in swimming and the last three form a springing or leaping organ. In a few forms the abdomen is reduced.

x Gammarus, Caprella.

Order 2. Isopoda........... Depressed forms with seven free thoracic somites. The abdominal appendages are in the form of 
II. TYPES IN DETAIL WITH THEIR SUBORDINATE GROUPS. 25

flattened plates and protect the gills, which are placed upon them. Some are reduced, parasitic forms.

$$
\times \text { Asellus, Porcellio. }
$$

Super-order 3. THORAKOSTRAKA. Eyes situated upon movable stalks. Carapace involving all or nearly all the thoracic rings. Brood cavity upon the ventral side of the flexible abdomen and protected by the sixth abdominal appendage and the terminal segment (telson).

Order I. Cumacea.......... Carapace small, involving only $3^{-4}$ thoracic somites, two pairs of maxillipeds, and six pairs of legs. Abdomen of female without appendages; of male with 3-2.

$$
x \text { Diastylis. }
$$

Order 2. Stomatopoda......... Carapace involving five thoracic somites, five pairs of maxillipeds, and three pairs of legs. Gills upon the abdominal appendages.

$x$ Squilla.

Order 3. Schizopoda.......... Carapace involving entire thorax, eight pairs of two-branched, gillbearing, thoracic legs. No maxillipeds.

x Mysis.

Order 4. Derapoda .......... Carapace large and heavy, involving the entire thorax, three pairs of maxillipeds, and five pairs of legs, of which the first bears heavy claws. Gills at base of thoracic feet upon the sides, protected by the edge of the carapace. $x$ Homarus, Cancer. 
SUPPLEMENTARY CLASS, TRILOBITEA.

An important group of fossil forms, presenting some superficial resemblance to the Isopods. They are oval and flattened in form, and possess a dorsal carapace, divided by two longitudinal grooves into three areas, one median (rhachis) and two lateral (pleura). The carapace consists of a cephalo-thorax, behind which are a varying number of freely movable somites sometimes called the "thorax," and terminated by a plate-like "pygidium," formed of several fused somites.

The ventral side is almost unknown. Probably each thoracic somite had a pair of crustacean-like legs, above which there may have been a pair of gills, protected by the overhanging edge of the carapace. Recently (1894) some finely preserved specimens have been discovered showing one pair of long antennæ.

The Trilobites appear to have close affinity to the branchiate Arachnoids, as well as to the genuine Crustacea.

Class II. TRACHeAta........ Terrestrial Arthropods, with one pair of antennæ; appendages numerous in the lower members of the class; in the higher ones few and definite in number. Respiration by means of branching tracheal tubes opening to the exterior by means of spiracles, placed along the sides of the body. A few are secondarily adapted for aquatic life, and breathe by numerous devices, mostly modifications of the tracheal system.

Sub-class I. Peripatoidea.......A group consisting of a very few tropical forms, isolated from one another, and found in all continents. In many respects they are more like Annelids than Arthropods, and form an interesting connecting link between the former and the genuine Tracheata. The body somites are all alike and the appendages, which are creased or folded rather than jointed, show no regional differentiation. Each somite has a pair of nephridia, 
opening at the base of the legs. Respiration is by tufts of tracheal tubes proceeding from irregularly distributed spiracles. There is but one important genus, Peripatus.

Sub-class II. MrruapodA........Generalized Tracheata, with the somites and appendages very similar to one another; i.e., with little regional differentiation. There is a distinct head, bearing antennæ, mandibles, and two pairs of maxillæ.

Order I. Chilopoda......... Depressed in form; a single pair of legs to each somite; mandibles well developed, fitted for predaceous life; first pair of legs transformed into a pair of biting jaws furnished with poison glands. $x$ Lithobius, Scolopendra.

Order 2. Dirlopoda......... Usually cylindrical in form, with a tendency to coil up when attacked; the primary somites coalesce in pairs, thus giving an appearance as though there were a double pair of legs to each of the very numerous somites.

$x$ Iulus.

Sub-class III. HEXAPODA (INSECTA). Body divided into three distinct regions or somite-complexes : head, thorax, and abdomen; the head bears four pairs of appendages: antennæ, mandibles, and two pairs of maxillæ; a lost pair appears in some embryos between antennæ and mandibles; the thorax bears three pairs of legs and usually two pairs of integumental folds used 
as wings; the abdomen consists typically of eleven somites with modified terminal appendages for palpation and oviposition. The higher insects have gained secondary larval forms and thus develop by a metamorphosis.

Order I. Thysanura.......... Minute wingless forms, with biting mouth parts, found in decayed wood and damp earth. They are the most primitive insects and have never developed wings. Some show rudiments of abdominal legs. Ametabolic; i.e., development direct. x Podura.

Order 2. Pseudoneuroptera ...Mouth parts biting, wings all alike, transparent, delicate, with lacelike venation. This group was formerly united with the Neuroptera, but has an active pupa (hemimetabolism).

$\times$ Libellula, Ephemera.

Order 3. Orthoptera........ Mouth parts biting, upper wings parchment-like, generally narrow, under wings membranous and often folded. Development hemimetabolic; i.e., pupa active.

$x$ Calopienus.

Order 4. Neuroptera......... Mouth parts biting, somewhat modified in Phryganida. Wings as in Order 2. Development holometabolic; i.e., pupa quiescent. $x$ Phryganea.

Order 5. Colzoptera......... Mouth parts biting, upper wings (elytra) forming hard shields for the protection of the membranous lower ones. Holometabolic. 
Thorax free and quite distinct from the posterior portion, thus dividing the body into three regions: head, pro-thorax, and meso- and metathorax + abdomen. Holometabolic. $x$ Carabus.

Order 6. Rhynchota (Hemip-

TERA)............... Mouth parts modified to form a straight jointed beak, which lies between the coxal joints of the legs. Wings either membranous and alike or with the outer diagonal half of the upper wings pergamenteous. Many forms wingless. Hemimetabolic.

$$
x \text { Coreus, Cicada. }
$$

Order 7. Lepidoptera........ Mouth parts a double-coiled proboscis, formed by the first maxillæ. Wings alike in texture, membranous, covered with minute colored scales. Holometabolic.

$x$ Papilio, Sphinx.

Order 8. Diptera...........Mouth parts variously modified, sucking, piercing, or lappingnever biting. Fore wings membranous, hind wings reduced to minute knobs-the so-called balancers. Holometabolic.

$x$ Culex, Musca.

Order 9. Hymenoptera........ Mouth parts biting, or biting and lapping; wings membranous, alike in texture, but hind pair reduced in size; body generally much constricted between thorax and abdo. men. Ovipositor of female generally accompanied by organs for sawing, boring, digging, or stinging, 
the latter modification equipped with a poison gland.

$x$ Vespa, Formica.

Class III. ARACHNOIDEA....... Head and thorax fused into a single piece, the cephalo-thorax, bearing six pairs of appendages, of which one is præ-oral. These may all be used as legs, or one or more pieces may be chelate and serve as mandibles or weapons of defence. In the lower forms the abdomen is elongated and segmented and may bear appendages, but in the higher forms it is consolidated and may even be fused with the cephalo-thorax. Respiratory organs originally lamellate gills, developed as adjuncts of the abdominal appendages. In the airbreathing forms they may be modified and reduced in number, or even replaced by a tracheal system, probably not homologous with that of insects.

Sub-class I. arachiomea Bratrchita. . Mainly fossil forms, all marine, gills lamellate, one pair of eyes in side of cephalo-thorax, and one pair of small ones anterior to these near the middle line. Coxal joints of the legs, or of some of them, forming spiny plates used in mastication.

Order I. Gigantostraka...... Fossil crab-like animals with long extended abdomen, which may or may not terminate in a spine.

$x$ Eurypterus, Plerygotus.

Order 2. Limuloidea......... Mainly fossil, with three surviving 
II. TYPES IN DETAIL WITH THEIR SUBORDINATE GROUPS. $3^{\mathrm{I}}$

species, the "horse-shoe crabs." These have a shortened abdomen, consolidated into a single piece, and bearing six plate-like appendages, of which all but the first bear gills. The larvæ pass through a so-called " trilobite" stage, in which they greatly resemble the extinct group of Trilobitea. $V$. supra, p. 26. This circumstance suggests a possible relationship between these groups. $\times$ Limulus.

Sub-class II. ARACHNoIdea Tracheata. . Mostly terrestrial, breathing either by gill-plates enclosed in pneumatic chambers, the so-called "lungs," or by tracheal tubes resembling those of insects. First two pairs of appendages serve as mouth parts, and are often chelate. Last four pairs serve as legs.

Order I. Scorpionidea.........Elongated forms, with a broad præ-abdomen of seven somites and a narrow tapering post-abdomen or "tail" composed of six somites and ending in a poisonous spine. Second pair of appendages enormously developed and chelate. Four pairs of "lungs."

$x$ Scorpio.

Order 2. Pseudoscorpionidea. Tiny animals found under bark (and sometimes in houses) resembling miniature scorpions, but without the tail. They breathe by tracheal tubes. $x$ Chelifer.

Order 3. Phalangida......... Entite body a shortened oval. Reduced abdomen closely applied to cephalo-thorax, but distinct and 
consisting of six (rarely eight) somites. Mandibles chelate. Legs very long and attenuated. Tracheal tubes with one pair of spiracles between thorax and abdomen. $x$ Leiobunum, Phalangium.

Order 4. Arachnida..........Abdomen unsegmented, swollen, and attached to cephalo-thorax by a stalk. Mandibles end in a simple claw with poison gland. Second pair of appendages leg-like, modified in male. Two to three pairs of spinnerets at end of abdomen. One to two pairs of "lungs" situated on abdomen. These may be also connected with a system of tracheal tubes.

$$
\text { × Epeira, Agalena. }
$$

Order 5. Acarina............Abdomen fused with cephalothorax; body unsegmented; appendages about mouth often modified to form a sucking tube; respiration by tracheal tubes or merely through integument; many parasitic forms.

$x$ Ixodes, Tyroglyphus.

There are several other Orders of Arachnoidea, but they are confined to the Tropics and of interest mainly to specialists.

SUPPlementary ARTHROPOD GROUPS (doubtfully referred to the Arachnoidea).

Pantapoda (Pycnogonida)...... Extremely attenuated marine forms with long slender legs and body of about the same diameter. Cephalo-thorax of six segments, of which the first are fused and possess 
a beak at the anterior end. Abdomen much reduced. Seven pairs of legs (or fewer), containing the reproductive organs and diverticula of the stomach. Special respiratory organs wanting.

$x$ Phoxichilidium.

TARDIGRADA. ............... Minute fresh-water animals, known as " water bears," with four pairs of very short legs bearing hooks; hermaphroditic, and without special organs of circulation or respiration.

$x$ Macrobiotus.

Pentastomidea (Linguatulina)... Worm-like parasites found in the lungs and nasal cavities of reptiles and mammals. They resemble Platyhelminthes, but their development is like that of the Arachnoidea. Legs reduced to two pairs of hooks about the mouth.

$x$ Pentastomum.

\section{TYPE VI. ECHINODERMATA.}

A type of marine animals which, in the larval stage, are bilateral and pelagic, but which, after a short larval life, attain through a singular metamorphosis a pentamerous radiate structure. The adults are characterized by the presence of calcareous elements in their integument which show all degrees of development from that of minute, scattered plates to a complete test or shell in which the separate plates are large and in close contact with one another. Locomotion is effected by a water-vascular (ambulacral) system which communicates with the exterior and contains sea-water.

Class I. HOLOTHUROIDEA....... Oval or vermiform Echinoderms covered by a leathery integument in which are imbedded minute calcareous plates and spicules. 
Around the mouth is a crown of fringed, retractile tentacles. Larval form the Auricularia.

Order I. Pedata........... Ambulacral feet present.

$$
x \text { Pentacta, Thyone. }
$$

Order 2. APODA.............Ambulacral feet wanting. $\times$ Synapta.

Class II. ASTERoIdeA.......... Star-shaped to pentagonal Echinoderms, with exo-skeleton in the form of a rough net-work studded with short fixed spines. Ambulacral feet in grooves on oral side.

Order I. Asteridea......... No definite boundary between disc and arms; larval forms the Bipinnaria and Brachiolaria.

Order 2. Ophiuridea........ Disc and arms distinct, the latter serpentine and very brittle. Larval form a Pluteus, similar to that of Class IV.

Class III. CRINOIdEA.......... Sessile forms, somewhat resembling Ophiuridea on stalks. The part corresponding to the disc of the latter is here called the calyx and is so placed that the mouth is above, surrounded by the many branched arms. Larval form oval in form, with ciliated bands running around it.

Class IV. ECHINOIDEA.......... Spheroidal, oval, or disc-shaped forms, with extensive exo-skeleton composed of large calcareous plates arranged in meridional rows, and beset with movable spines. The ambulacral feet project from foramina in the plates of certain rows, called ambulacral. Larval form a Pluteus. 
Order I. Regularia..........Mouth and anus in the centre of their respective surfaces.

$x$ Arbacia, Toxopneustes.

Order 2. Clipeastroidea...... Mouth central, anus eccentric, often near the outer margin.

$x$ Echinarachnius.

Order 3. Spatangoidea........ Mouth and anus both eccentric.

$x$ Spatangus.

Aside from these classes there are two wholly fossil groups, often reckoned as classes, the CySTIDEA and the Blastoidea. These seem allied to the Crinoids. The CrstideA possessed irregular calyx plates and some of them were without arms. The BLASTOIDEA were all armless, but were regular in structure, with well-marked ambulacral areas.

\section{TYPE VII. PREVERTEBRATA.}

A group of apparently very dissimilar animals, all of which possess gill slits in the pharyngeal region, a dorsal nervous system and a more or less well-defined endoskeletal rod, the notochord. They are thus seen to be allied to the Vertebrates and undoubtedly represent the much-modified descendants of the transitional forms which became the ancestors of that group.

Class 1. ENTEROPNEUSTA......Small, worm-like animals, with habits similar to Annelids, and found between tide-marks in mud flats. At the anterior end is a conical and flexible proboscis with which the animal pushes its way through the mud; this is followed by the "collar" at the upper ventral edge of which is the mouth; below this is a respiratory region, perforated by pairs of gill-slits which communicate with the pharynx. A small dorsal diverticulum at the anterior end of the pharynx represents the notochord.

$\times$ Balanoglossus, Harrimanza. 
Cephalodiscus and Rhabiopleura, two sessile forms formerly classed as Order, Pterobranchia, under Bryozoa, have been found to resemble Balanoglossus. In young buds of the former a division into proboscis, collar, and body may be seen. There is also a single pair of gill-slits, and a dorsal diverticulum of the intestine (= notochord ?) lying under the dorsal nervous system. In Rhabdopleura no gill-slits have been detected, but in other respects the structure is similar to Cephalodiscus.

Class II. TUNICATA.........A group of marine animals which are free-swimming during larval life at least, and which possess an endoskeletal rod (notochord) in the tail. The body of the adult is enclosed in a mantle or " tunic," which may be gelatinous, leathery or cartilaginous, and possesses an incurrent or oral and an excurrent or anal orifice. The pharynx is perforated by gill-slits which may become so numerous as to convert the entire pharyngeal wall into a lattice-work. Many species are sessile when adult and in these the intestine becomes U-shaped and the two mantle openings approximate one another, while in the free-swimming forms the intestine is straight and the two orifices are situated at the ends.

Sub-class I. Perenimchordata.... Free-swimming forms, resembling the larvæ of higher Tunicates. They possess a long tail provided with a skeletal axis, the notochord. Pharynx with a single pair of gillslits. No definite mantle but a gelatinous envelope.

$x$ Appendicularia.

Sub-class II. Ascidaces........ Body sac-like, with pharyngeal wall completely perforated with 
gill-slits. The typical members of this class are solitary and sessile, with the two orifices approximated. Some are colonial with certain parts in common, and in a few of these cases the colony is free-swimming and pelagic.

Order 1. Ascidiø........... Sessile forms, either solitary (monascidia), or colonial (synascidia), and arranged in generally stellate groups, known as conobia.

x Bolienia, Botryllus.

Order 2. Pyrosominet ........ Free-swimming, transparent colonies of a cylindrical or coneshaped form. Incurrent openings upon the exterior, cloacal openings in the interior.

x Pyrosoma.

Sub-class III. Thaliacea. ....... Free-swimming, pelagic forms, transparent and surrounded by a gelatinous tunic. Pharynx with either two rows of gill-slits or with a single pair of large gill-slits. Oral and cloacal openings at opposite poles. The members of this group often show a remarkable alternation of solitary and colonial generations, or even a still more complicated development.

Order 1. DoLIoLre.......... Two rows of gill-slits. Muscle bands in the form of closed rings. Mantle thin. Generative cycle complex, including one sexual and two asexual generations.

$x$ Doliolum.

Order 2. Salpire..........A single pair of gill-slits. Muscle bands not in the form of complete 


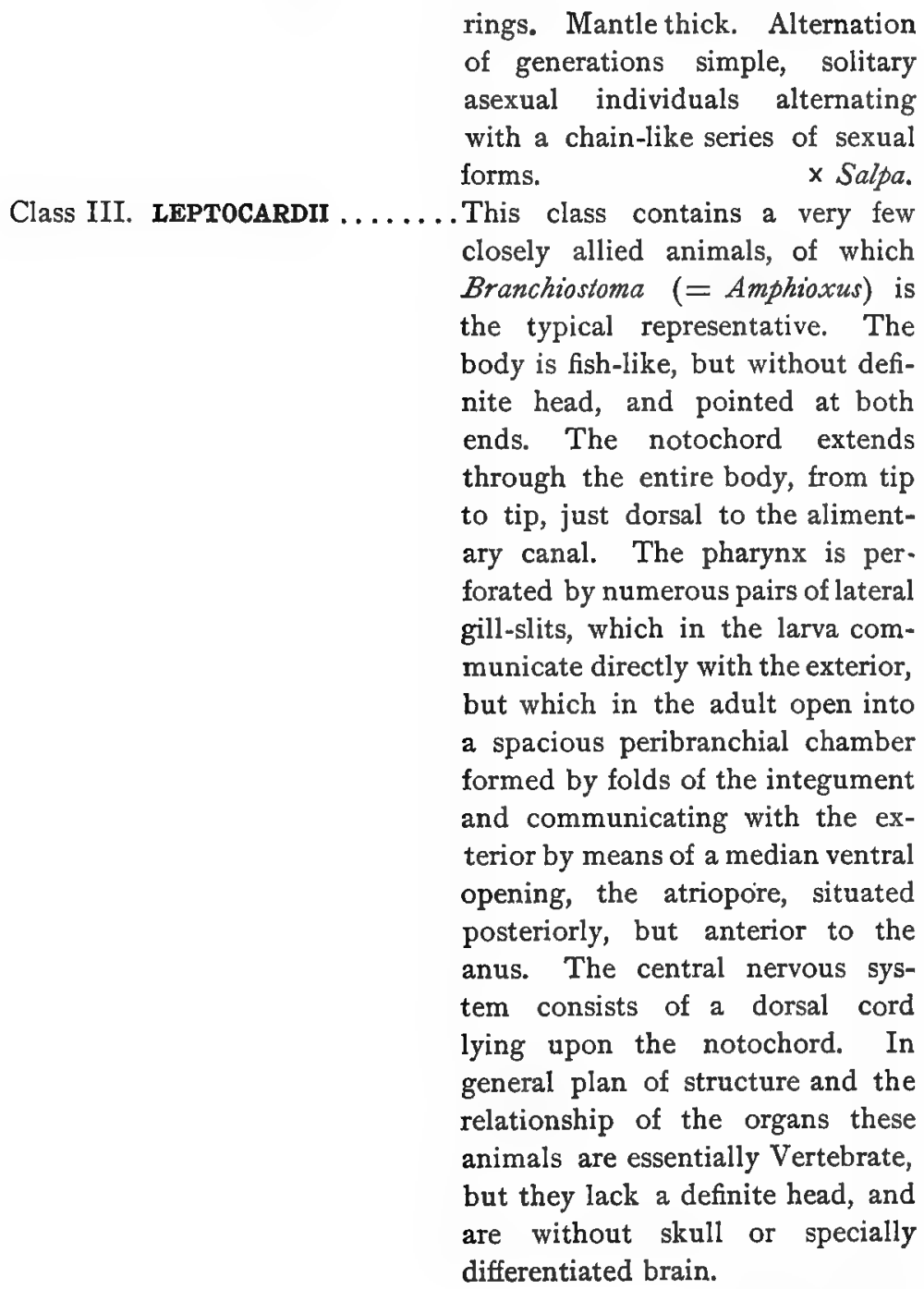

$\times$ Branchiostoma. 


\section{TIPE VIII. VERTEBRATA.}

Division I. CTCLOSTOMIATA. Vertebrates with a circular suctorial mouth armed with chitinous teeth; no jaws; 6-7 pairs of circular gill-openings.

Class. MARSIPOBRANCHII...... The only class included hete, with characteristics of the Division. Its two sub-divisions have the ralue of Families, as follows:

Family 1. Petromyzontide...... Nasal cavity a median blind-sack. (Lamprey eels.) Nouth without tentacles. They attach themselves bo their circular mouth to the sides of fishes and suck their blood. Fresh-mater and marine forms.

$x$ Petromyzon.

Family 2. Myximide.......... Nasal sack prorided with an inner (Hag-fish.) palatal opening. Mouth with tentacles. Habits more parasitic than the former. They push their way even into the body-cavity of other fish and consume their viscera. All marine. $\times$ Mrxine.

Division II. GNATHOSTOMLA. Tertebrates with mouth in the form of a transverse cleft, supported by two jaws; teeth usually present, composed of enamel and dentine.

4. ANIMNIA .......... Embryo without amnion or other fœtal membranes; some have langs, but all breathe by gills during at least a portion of their life; cold-blooded.

Super-class I. ICHTHYOPSIDA. A group equivalent in extent to Anamoria q. $\overline{\text {. }}$. 
Class I. PISCES.............Aquatic Anamnia, with branchial respiration. Paired limbs in the form of fins (ichthyopterygia). Integument generally produces scales, which contain bony material produced by the corium. Heart with one auricle and one ventricle.

Order I. Selachil (ElasmobranchiI).. Skeleton cartilaginous, scales placoid. Tail heterocercal. 5-7 separate gill openings without operculum.

x Squalus, Raja, Chimcera.

Order 2. Ganoider........... Skeleton more or less reinforced by bone. Scales typically rhomboid in form and with a hard polished surface (= ganoid). Tail heterocercal. Gill-slits with operculum. $\quad x$ Acipenser, Lepidosteus.

Order 3. Dipnor............ Skeleton mainly cartilaginous. Notochord persistent. Paired fins with a central skeletal axis and with or without lateral rays. Median fin continuous around tail. Swimming-bladder functions as lung. Gills with operculum. In one species small external gills also. A very small, but isolated group, including 3-4 living species.

$\times$ Ceratodus, Protopterus.

Order 4. Teleostei....... . Skeleton mainly osseous. Scales cycloid or ctenoid. Tail homocercal. Gills provided with an operculum.

Class II. AMPHIBIA........... Skin naked, very glandular and slimy. Gills, external and inter- 
II. TYPES IN DETAIL WITH THEIR SUBORDINATE GROUPS. $4 \mathrm{X}$

nal, present at some stage, generally transitory. Lungs usually present, with larynx and trachea. Paired limbs of the hand-form (cheiropterygium) with normally five digits, often reduced in number. Two occipital condyles.

Order I. URODELA............Body elongated. Tail persistent. In some of the lower members of the group one or two gill-slits persist throughout life, and in a few, the external branchiæ also persist. Typically lungs are present in the form of simple, attenuated sacs, but in some cases they are wanting and are functionally replaced by a secondary respiratory organ formed by the walls of esophagus and pharynx and worked by muscles.

$x$ Necturus, Desmognathus.

Order 2. Gxmnophiona........ Serpentine subterranean forms without tail, limbs or gills. Integument with minute scales sunken in pits.

$x$ Coecilia.

Order 3. ANura........... Compact, cephalized forms, with tail present in larval life only. Hind legs enormously developed and used for leaping and swimming. No gills when adult. $\times$ Rana, Bufo, Hyla, Pipa.

B. AMNIOTA ............. Embryo enveloped in an amnion; breathe by lungs and never by gills; mainly terrestrial.

Super-class II. SAUROPSIDA.... Skin thin and dry, covered with a 
profusion of chitinous organs, often of great complexity; embryo developed within an egg; a single median occipital condyle.

Class III. REPTILIA.......... Integument covered with scales, horns, and other structures of epidermic formation. Glands confined to a definite locality (femoral glands of lizards) or wanting.

The Orders of living reptiles are conveniently arranged under the the two groups of Plagiotremata and Hydrosauria, but if the fossil Orders were included, this classification would require some amendment.

Group I. PLAGIOTREMATA..Cloacal opening transverse, behind which, in the male, are paired organs of copulation. Body uniformly covered by delicate scales, which are cast off yearly, often as a single piece. Habits mainly terrestrial and arboreal. Quadratum movably articulated with skull (except in Rhynchocephalia, v. infra).

Order 1. Lacertilia......... Four well-developed limbs in the typical forms, and sternum or shoulder girdle present in forms in which the limbs are reduced.

Order 2. Ophidia ........... Body very much attenuated, limbs wanting, no rudiment of shoulder girdle or sternum. A single lung developed (right). Other paired organs placed the one behind the other.

$x$ Crotalus, Python.

A single species of a very ancient type of lizard occurs in New Zealand Sphenodon (Hattena) punctata. The quadrate is immovable, ventral ribs and abdominal sternum are present, the vertebræ are amphicolous. It is referred to the Order Rhynchocephalia. 
Group 2. HYDROSAURIA... Cloacal opening oval in shape, its longer axis longitudinal. A single organ of copulation in the male, anterior to the cloaca. Scales large and irregular, often reinforced by bony plates, which may coalesce to form dorsal and ventral shields. Mainly aquatic in habits. Quadratum immovably attached to skull.

Order 3. Chelonia......... . Body enclosed by dorsal and ventral shields, formed partly by elements of the endo-skeleton and partly from the integument. Teeth functionally replaced by horny beak, with sharp cutting edge. $x$ Chrysemys, Chelone.

Order 4. Crocodilia........... Body elongated, covered by large plates, which do not coalesce.

Thoracic and abdominal sterna present, connected by ventral and dorsal ribs. Teeth large, in alveoli. $x$ Alligator, Crocodilus.

Our knowledge of Reptilia is greatly increased by the discovery of several important fossil Orders. The THEROMORPHA, very primitive in some particulars, possessed certain anatomical characteristics which are suggestive of the Mammalia, and are thus considered by many as ancestors of the latter group. The MOSASAURIA, an Order of snake-like marine reptiles, were allied to both Lacertilia and Ophidia, and it is possible that surviving members of this group are occasionally seen and called "sea-serpents."

The PTEROSA URIA were allied to the Lacertilia, and possessed membranous expansions of the integument of the arms and fingers, by which they could fly. The PLEISIOSAURIA and ICHTHYosauria were hydrosaurs, the former somewhat resembling turtles, the latter, crocodiles. The DINOSAURIA included some enormous terrestrial forms with massive skeletons, e.g., Brontosaurus and Iguanodon. Other smaller Dinosaurs may have been the precursors of birds. They walked mainly upon their hind feet, possessed pneumatic cavities in their bones, and showed many other avian characteristics. An important form is Compsognathus, which shows affinity to Archaopteryx (see introduction to Aves). 
Class V. Aves *...........Warm-blooded Vertebrates, showing many reptilian characters, but differing from them in the possession of feathers, which are epidermic structures closely related to scales. The anterior limbs, modified to form wings, generally give the animal the power of flight. Quadrate bone movably articulated with the skull. A single occipital condyle.

The classification of this group which has obtained until recently, and the one still found in the majority of text-books, is artificial in character and results from an attempt to differentiate for convenience the enormous number of living species which are too nearly alike morphologically to sanction such a division. "The Order of birds is so uniform in its structural features that it is difficult to find important characters to differentiate the twelve thousand known species into convenient groups. As a result, ornithologists have raised the number of minor groups into so-called Orders, which are scarcely of Family rank, if we are to accept the rules in vogue in other groups of Vertebrates" (Kingsley).

For convenience the lesser groups, usually described as Orders, are here retained as Sub-orders, although hardly equivalent to such groups elsewhere.

Sub-class I. SAURURE........ Jaws containing teeth, tail elongated, vertebrated throughout, and with a pair of contour feathers to each vertebra; digits of the wings not anchylosed, partially free, three of them provided with claws. This group rests upon the remains of a single fossil species (two specimens) from the Jurassic limestone of Solenhofen, Germany.

$\mathrm{x}$ Archoeopteryx.

Note. - The classification of birds as here given follows closely that of Kingsley (Vertebrate Zoölogy, 1899) which, in its turn, is based upon the comparatively recent investigations of Furbringer and others. The more familiar names for the groups of carinate birds are added to Order 3 . Euornithes, as its sub-divisions. 
Sub-class II. ODomToRmTHEs. . . . . "Toothed-birds," a group based upon fossil, bird-like forms, found in the cretaceous beds of Kansas and Colorado. The remains repreresent two types, sufficiently distinct to constitute different orders.

Order I. Odontoholce........ Ratite birds, with teeth in continuous alveolar grooves; halves of mandible united by cartilage; wings much reduced, containing humerus alone; caudal vertebræ expanded and paddle-like. Feet fitted for swimming.

$x$ Hesperornis, Lestornis.

Order 2. OdONTORME.......... Carinate birds with teeth set in separate sockets; halves of mandible united by cartilage. Wings strong and powerful.

$x$ Ichthyornis, Apatornis.

Sub-class III. EURHIPIDURE..... This sub-class includes all living birds. They are toothless, with two halves of the mandible anchylosed; a short tail ending in a pygostyle of several fused vertebræ.

Order I. Dromagonathi...... Running birds with rudimentary or small wings and large, heavy legs. An important anatomical character is the dromæognathus skull, i.e., one in which the palatine bones are separated from the rostrum by a wide vomer. Feathers of the down type (rami not united). This Order includes the old group of "Ratilae," besides a few others, extinct and recent, some being carinate.

$\times$ Struthio, Apteryx, Tinamus. 
Order 2. Impennes.......... Aquatic birds with short, paddlelike wings used only for swimming; no distinction of feathered and featherless areas. Feathers covering wings scale-like; dorsal vertebræ opisthocœlous and movable upon one another; uncinate processes not anchylosed to ribs; the three elements of the tarso-metatareus incompletely fused, leaving slit-like foramima, a peculiarity possessed by no other living forms.

$x$ Aptenodytes, Spheniscus.

Order 3. Euornithes ........ Nearly all living birds belong here. The sternum is carinate and the wings well developed. The skin possesses well-marked feathered and featherless areas and the wings and tail are furnished with contour feathers.

$$
\times \text { Anser, Aquila, Gallus, Passer. }
$$

The numerous sub-divisions of this Order, considered here for convenience as Sub-orders, may be grouped in three groups in accordance with a fundamental anatomical characteristic, viz.: the relationship existing between the maxillo-palatine processes and the vomer as seen upon the ventral side of the skull. Thus, in the desmognathous type the maxillo-palatine processes are united in the median line, forming a bony roof to a part of the palate; while in the schizognathous and ægithognathous types the maxillo-palatine processes are separated from each other, leaving a median, longitudinal cleft in the bony palate. These two last types are distinguished from each other by the shape of the anterior end of the vomer, which is pointed in the Schizognathas and broad and notched in the Agithognatha.

The groups and their sub-divisions are arranged as follows:

Group A. Desmognathæ.

Sub-order I. Steganopodes.....

$x$ Pelicanus.

Sub-order 2. Lamellirostres.....

Sub-order 3. Herodiones.......

Sub-order 4. Raptores.........

Sub-order 5. Coccygomorpha...

Sub-order 6 . Psittaci. ....... $\mathrm{x}$ Anser, Cygnus, Anas. $\mathrm{x}$ Ardea, Ibis, Ciconia. $\times$ Aquila, Strix. $x$ Cuculus, Halcyon. x Psittacus, Cacatua, Conurus. 
Group B. Schizognathae.

Sub-order 7. Cecomorpha....

Sub-order 8. Turbinares......

x Podiceps, Alca, Larus, Slerna.

Sub-order 9. Gralla ........

x Diomedea, Fulmarus.

Sub-order 10. Gallina........ $x$ Grus, Charadrius, Scolopax.

Sub-order I I. Columba....... $x$ Gallus, Perdix.

Sub-order I 2. Trochilida...... $\times$ Columba, Didus.

Sub-order I3. Pici.......... $\times$ Trochilus, Lophornis. $x$ Picus, Colaptes.

Group C. Egithognathæ.. ......

Sub-order 14. Passeres........ (Over half the known species of birds belong here.)

$x$ Passer, Tyrannus, Hirundo, $P a-$ radisea, Corvus.

Super-class I. MAMMALIA .... Same as class: Mammalia. q. v. Class VI. MAMMaLIA .........Warm-blooded vertebrates. Body clothed with hair; young nourished by milk, a secretion of integumental glands. Quadrate in middle ear, two occipital condyles.

Sub-class I. Prototheria ....... . Low oviparous mammalia with reptilian characteristics, such as an episternum and well developed coracoids. The young, immature when hatched, are brooded either in a nest or in a brood pouch temporarily developed. No localized mammary glands or nipples; but the integument of the mammary pocket is lactiferous. Alimentary canal, urethra, and reproductive ducts open into a common cloaca.

Order I. Monotremata.......With characteristics of the Subclass. Ornithorhynchus, Eckidna.

Two extinct Orders of Prototheria have been established. The Protodonta, represented by lower jaws of two Jurassic species, and the Multituberculata, represented by several genera founded upon numerous teeth from the Upper Jurassic and Lower Eocene. The separation of these Orders rests upon dental characteristics. 
Sub-class II. EDTHERI ..........Cloaca divided transversely into intestinal and genito-urinary tracts; mammæ furnished with nipples; viviparous, early development takes place in uterus; no episternum; coracoid reduced and fused with scapula in adult.

Group A. Marsupialia (Didelphia). . Division of cloaca seldom complete. Young are born in an immature condition and sheltered in an external integumental pouch (marsupium) on the ventral surface of the abdomen; two lateral uteri and vaginæ, sometimes incompletely united.

Order I. Polyprotodontia..... More than three incisors on each half of upper jaw.

$\times$ Didelphys, Perameles.

Order 2. Diprotodontia....... Three incisors, or less, on each half of upper jaw.

$x$ Macropus, Phascolomys.

Group B. Placentalia (Monodelphia). . Young nourished in uterus of mother by a capillary mass, the placenta, which adheres to the uterine wall and is connected with the embryo by the umbilical cord. Anus separated from the uro-genital sinus by a perinaum.

Order 3. Edentata......... Teeth either wanting or in condition of retrogressive metamorphosis. Incisors and canines generally fail. Large number of sacral vertebræ. Placenta indeciduate, diffuse, or occasionally discoidal.

$x$ Dasypus.

Order 4. Sirenia..........Aquatic forms with only the anterior limbs developed. Teeth often 
wanting; molars, when present, resemble those of ungulates. Sparsely hairy. A single pair of pectoral mammary glands. Placenta indeciduate, diffuse. $\quad \times$ Manatus.

Order 5. Cetacea............Aquatic forms with naked skin, provided with hair in embryo. Hind limbs fail externally; rudiments under skin. Mammary glands in folds on the sides of the vagina. External nares in top of head connecting directly with a tubular prolongation of the larynx. Placenta indeciduate, diffuse. $\times$ Balana.

Order 6. Artiotoactrua.........Hoofed mammals with an even number of toes, of which two (3 and 4) are the best developed, resulting typically in the cloven hoof. The præ-molars, 3-4, are smaller than the molars. Many members of this Order are ruminants. Placenta indeciduate, cotyledonal in most ruminants, in other cases diffuse. $\quad x$ Bos, Hippopotamus.

Order 7. Perissodactria...... Hoofed mammals with an odd number of toes, five, three or one, the middle one being the best developed. Præ-molars equal the molars in size. Integument often very thick. Placenta indeciduate, diffuse. $\quad x$ Rhinoceros, Equus.

Order 8. Proboscidia.........A group allied to the two previous Orders, but with five stout toes furnished with hoofs, making a ponderous rounded foot. The snout is enormously prolonged, forming a muscular proboscis 
tipped with a sensitive finger-like process. One pair of incisors, which develop into mammoth tusks. (In recent forms it is those of the upper jaw. Lower incisors in Dinotherium.) Placenta deciduate and zonary. $x$ Elephas.

Order 9. Hyracoidea........A single family of small, rodentlike mammals with five digits on fore foot (two rudimentary) and three on hind foot. Four upper and four lower incisors, outer upper ones early deciduous, leaving inner ones, which are chisel-like and continue growth as in Rodentia. Placenta deciduate and zonary.

$x$ Hyrax.

Order 10. Carnivora......... Beasts of prey with sharp well developed canines and pointed molars. The toes are armed with claws, which may become sharp and retractile. Placenta deciduate and zonary. There are two groups, one terrestrial, Fissipedia, with toes separate, and one aquatic, Pinnipedia, with toes strongly webbed, forming paddles. $x$ Felis, Phoca.

Order I . Rodentia.........A group of small animals with teeth fitted for gnawing. One pair of incisors in each jaw develop into sharp cutting chisels; the others are usually wanting. $\mathrm{Ca}$ nines wanting. The molars are fitted with transverse ridges for cutting. Placenta deciduate and discoidal. $x$ Mus, Sciurus.

Order I 2. INSECTrVORA....... Small insect-eating mammals with 
II. TYPES IN DETAIL WITH THEIR SUBORDINATE GROUPS. $5^{\mathrm{I}}$

the teeth prolonged into sharp points. Canines small or wanting. Placenta deciduate and discoidal.

$$
\times \text { Talpa. }
$$

Order 13. Cheiroptera....... The only flying mammals. Toes of anterior limb exceedingly attenuated, thus forming a framework for a thin leathery web, which also includes the hind limb and tail. Thumb of fore limb and all the hind toes free. Teeth pointed as in Insectivora. In many respects similar to the next Order. Placenta deciduate and discoidal.

$x$ Vespertilio.

Order 14. Prosimin...........A gtoup of animals closely allied to the apes, but of a generally lower structure. Appendages hand-like, with opposing thumbs, but with a double uterus, and a diffuse though deciduate placenta. The nails are developed into claws. $\times$ Lemur, Tarsius.

Order 15. Primlates......... Toes with flat nails. Appendages more or less hand-like, and generally fitted with opposing thumbs for grasping. One pair of pectoral mammary glands. Placenta deciduate and discoidal.

Sub-order I. Platyrrhini...... Nose flattened, nostrils separated by a broad septum, so that their orifices look outward. Natives of the Western Hemisphere $\times$ Cebus.

Sub-order 2. Catarrhini....... Internasal septum thin. Nostrils look forwards and downwards. Natives of the Eastern Hemisphere. $x$ Cercopithecus, Gorilla. 
Sub-order 3. Anthropini...... Nose as in Sub-order 2. Thumb more movable-great toe less so.

Hair reduced. Erect position normal. $x$ Pithecanthropus, Homo. 


\section{ARTIFICIAL KEY FOR THE DETERMINATION OF SPECIMENS.}

I. Entire animal consists of a single cell, though occasionally with more than one nucleus; either independent or arranged in the form of a colony...................... Protozoa.

II. Animal multicellular, usually of an appreciable size; when minute, then almost always with certain definite organs, such as an intestinal canal, ciliated bands, paired limbs, etc.

A. Structure radiate.

I. Parts in $2 \mathrm{~s}, 4 \mathrm{~s}, 6 \mathrm{~s}$, etc.

(a) Nettle-cells for defense, placed upon tentacles or other exposed parts; both free-swimming transparent forms (" meduse") and sessile, vase-shaped forms ("polyps"), the latter usually colonial. Apical (= ab-oral) pole non-sensitive, serving in sessile forms as place of attachment........... Cnidaria.

(b) Free-swimming, transparent, pelagic forms, with eight meridional rows of swimmingpaddles. Apical pole furnished with sense-

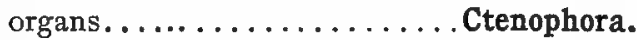

2. Parts in $5 \mathrm{~s} \ldots \ldots \ldots \ldots \ldots \ldots$ Echinodermata.

3. Parts not in a definite number, but animal more or less vase-shaped or cylindrical and with an apical excurrent opening, and minute incurrent pores along the sides; no tentacles; walls usually thick and their substance filled with a skeletal support of either spicules or of horn threads.... Porifera.

B. Structure bilateral, or nearly so.

I. Body externally segmented (or apparently so). 
(a) Appendages consist of fleshy, jointless lobes, beset with bristles; or else of the bristles alone, arranged in paired lateral groups.

Annelides.

(b) Appendages jointed, and usually differentiated into various sorts of limbs, with different functions................. Arthropoda.

(c) Appendages none; suckers at ends of body, which is flat and very finely segmented.

Hirudinea, sub Annelides.

(d) Appendages none; body composed of "links" which increase in length posteriorly, and which have the appearance of somites; genital pores on edges of links; anterior end head-like, but with no mouth; usually equipped with hooks and suckers.

Cestodes, sub Vermes.

2. Body segmentation not really external, but marked in the muscular system in the form of V-shaped lines which are seen through the transparent skin. No head, but pointed at both ends.

Amphioxus, sub Prevertebrata.

3. Body segmentation not apparent externally, but marked in the muscles of the trunk and in the trunk portions of the internal skeleton; two pairs of paired limbs, one or both of which may be reduced................... Vertebrata.

4. Body unsegmented (at least apparently so).

(a) Colonial, i.e. animals in groups, with organic connection between them or between their skeletal supporting structure. All aquatic.

* Sessile, aquatic.

† Each animal in a "cell" into which it may be withdrawn; ciliated tentacles around the mouth. Marine and in fresh water....Bryozoa, sub Vermes. 
† Animals bag-shaped, with incurrent and excurrent orifices, of which the latter may be held in common by the colony. Arrangement of animals in rows, rosettes, bunches, etc. All marine.

Ascidiacea, sub Prevertebrata.

** Free-swimming, all marine.

†Colonies cylindrical or conical, with one end open; separate animals tubular, with an opening at either end.

Ascidiacea, sub Prevertebrata.

†† Colonies chain-like, in single or double rows; separate animals cask-shaped, with zone-like bands; transparent.

Thaliacea, sub Prevertebrata.

(b) Solitary, or, if associated, without organic continuity.

* Sessile, aquatic.

† With two calcareous shells, dorsal and ventral. Two spiral, ciliated arms supported by skeleton within the shell.

Brachiopoda, sub Vermes.

†f With calcareous shells, but not as above and without the spiral arms........ Some Mollusca.

计 Microscopic forms in tubes. Ciliated lobes at free end. Rotifera, sub Vermes.

H†† Bag-shaped, either with or without a stem; two openings, incurrent and excurrent, Ascidiacea, sub Prevertebrata. 
** Locomotive, or at least unattached.

$\dagger$ Body worm-like, round or flat.

No shell.

† Body cylindrical, usually pointed at the anterior end; mostly parasitic.

Nematelminthes, sub

Vermes.

¥ Body flattened and capable of considerable elongation and contraction; mostly parasites.

Platyhelminthes, sub

Vermes.

廿⿻ Anterior portion cylindrical, succeeded by a narrow zone, the "collar." Posterior portion somewhat flattened, live in burrows in sand of seacoast.

Enteropneusta, sub Prevertebrata.

t† Body not worm-like.

$\ddagger$ Body soft and slimy, covered dorsally by an integumental duplicature, the mantle, which usually secretes a shell; marine, fresh-water, and terrestrial forms.

Mollusca.

¥ Pelagic, transparent forms; cask-shaped and with zone-like bands.

Thaliacea, sub Preverte-

brata. 
柾 Pelagic, tadpole-shaped animals, with long, flattened tail; body with incurrent and excurrent orifices.

Ascidiacea, sub Preverte-

brata.

杫较 Minute, transparent pe-

lagic organisms; possess ing bands of cilia. [Here belong the larval forms of Echinoderms, Nemerteans, Enteropneusta, some Annelids and other marine Invertebrates.]

NotE. - Nearly every important group possesses members which live as parasites either upon or within the bodies of other animals, and these, especially when in the latter position, often become so much modified that the usual characteristics of the groups to which they belong no longer apply to them. In some cases these modifications are so great that the real affinities may be learned only by a careful study of the embryological development, in some stage of which the animals are apt to resemble their free-living allies. Of these modifications the most usual are a reduction or entire loss of the locomotive organs and those of special sense, and the acquirement of suckers, hooks, and other adhesive organs; aside from this the general shape becomes vermiform or sac-like. It is thus impracticable to attempt to include the more reduced parasitic forms in the above key, and although many of them may be found and their position determined by its aid, it will be necessary in other cases to consult some more special authority. As this key is intended, however, for the beginning student only, and as the study of these parasitic forms belongs to those more advanced in the science, it will doubtless prove a sufficient aid to those for which it is designed. 








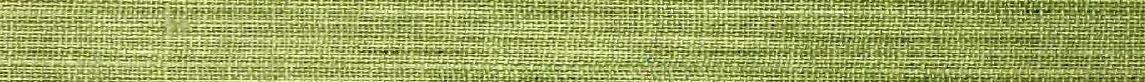

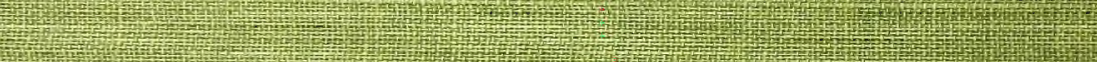

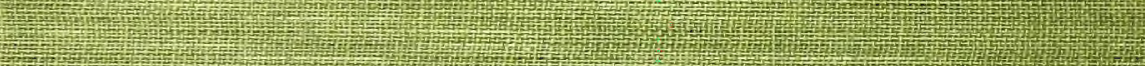

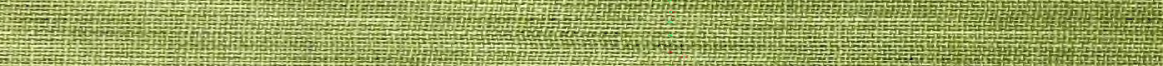

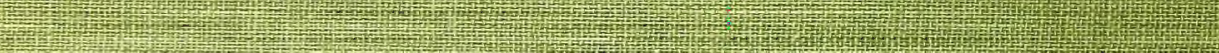
D.7. H.

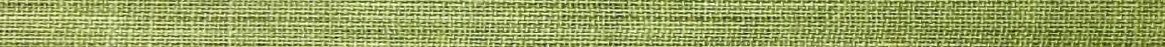

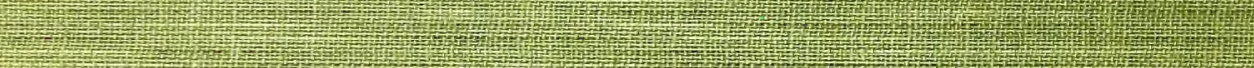

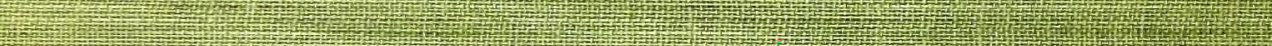

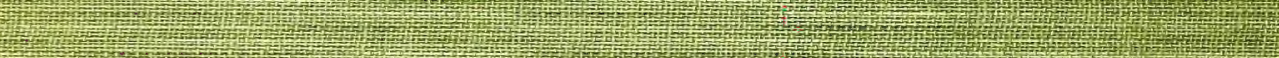

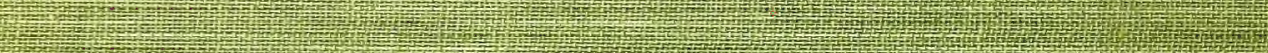

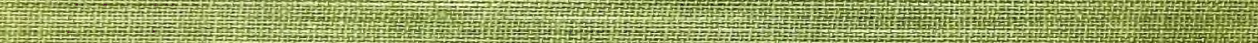

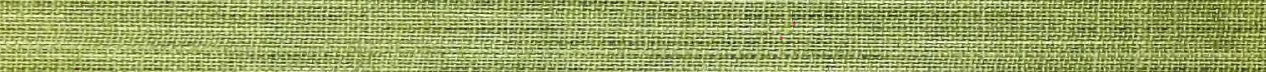

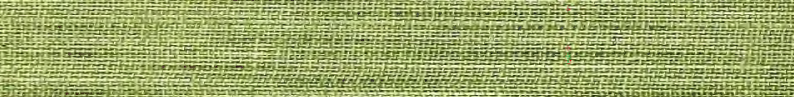
-

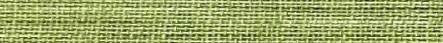
H. nu

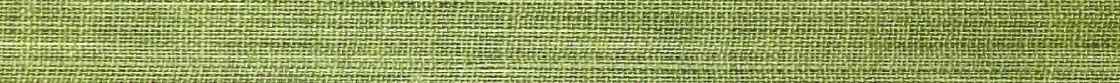
2.

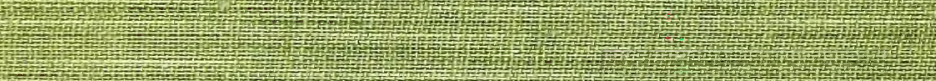

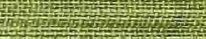

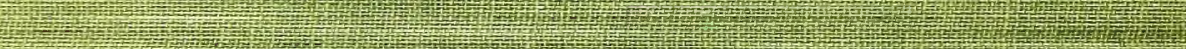

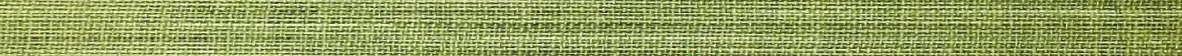

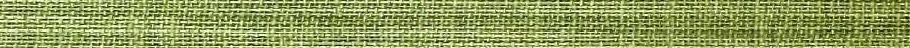
1.

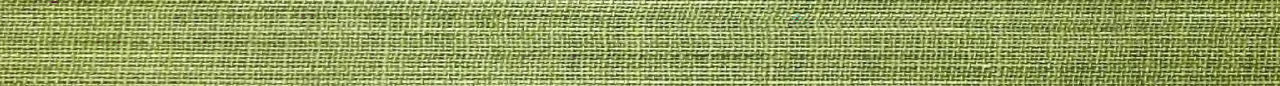

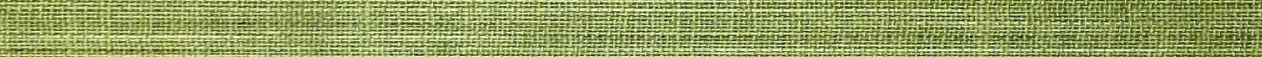
H

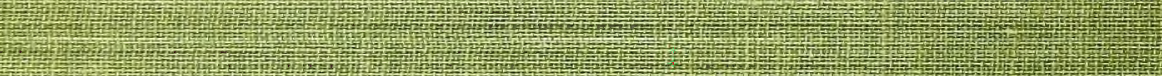

H.

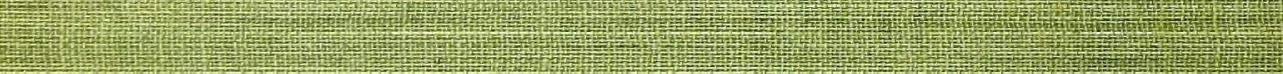
D. EF

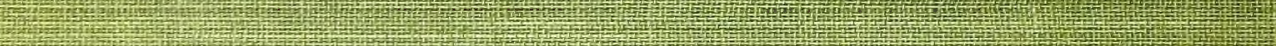

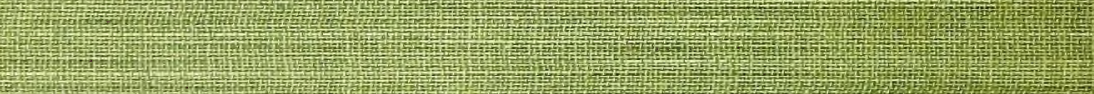

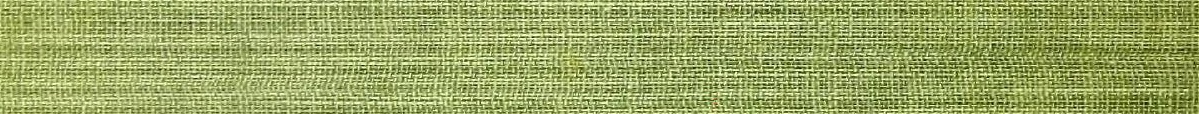
1. STH

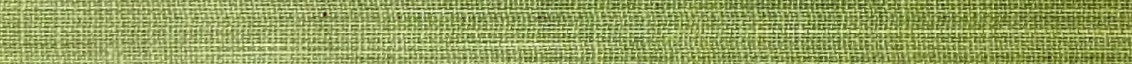

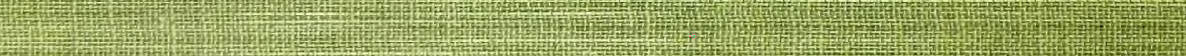
H.

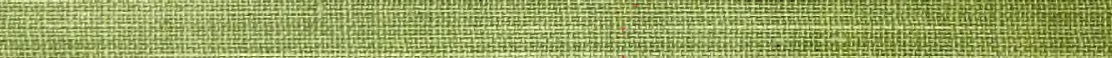

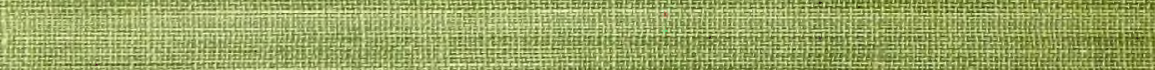

